\title{
Warfarin alone or with aspirin was superior to aspirin alone after acute myocardial infarction but increased bleeding
}

\author{
Hurlen M, Abdelnoor M, Smith P, et al. Warfarin, aspirin, or both after myocardial infarction. $N$ Engl J Med \\ 2002;347:969-74.
}
QUESTION: In patients who had an acute myocardial infarction (MI), what is the efficacy and safety of long term treatment with warfarin plus aspirin, warfarin alone, or aspirin alone?

\section{Design}

Randomised (allocation concealed*), blinded \{data collectors, outcome assessors, monitoring committee, and data analysts $\} \uparrow, *$ controlled trial with mean follow up of 1445 days (about 4 y) (Warfarin, Aspirin, Reinfarction Study [WARIS II]).

\section{Setting}

20 hospitals in Norway.

\section{Patients}

3630 patients $<75$ years of age who were admitted to hospital for, and had survived, an acute MI. Exclusion criteria included malignant disease. Follow up was $99.6 \%$.

\section{Intervention}

Patients were allocated to warfarin, with the goal of achieving an international normalised ratio (INR) of 2.0-2.5, plus aspirin, $75 \mathrm{mg}$ daily $(\mathrm{n}=1208)$; warfarin with the goal of achieving an INR of 2.8-4.2 ( $\mathrm{n}=1216)$; or aspirin, $160 \mathrm{mg}$ daily $(\mathrm{n}=1206)$.

Source of funding:

Norwegian Council on Cardiovascular

Disease.

For correspondence: Dr M Hurlen, Ullevål

University Hospital,

Oslo, Norway.

Mette.Hurlen@ulleval.no

Abstract and

commentary also

appear in ACP Journal

Club.

\section{Main outcome measures}

The main outcome was the composite measure of death, nonfatal reinfarction, or thromboembolic stroke, whichever occurred first. These outcomes were also separately reported.

\section{Main results}

Analysis was by intention to treat. Both warfarin groups had lower rates for the main composite measure, nonfatal reinfarction, and thromboembolic stroke than the

Warfarin or warfarin plus aspirin (Asp) v ASP after acute myocardial infarction at mean follow up of 1445 days

\begin{tabular}{|c|c|c|c|c|}
\hline Outcomes & Comparisons & Event rates & RRR (95\% Cl) & NNT (CI) \\
\hline \multirow[t]{2}{*}{$\begin{array}{l}\text { Composite } \\
\text { outcome§ }\end{array}$} & Warfarin + Asp v Asp & $15 \%$ v $20 \%$ & $25 \%$ (11 to 37 ) & 20 (12 to 51$)$ \\
\hline & Warfarin $v$ Asp & $17 \%$ v $20 \%$ & $16 \%(1$ to 29$)$ & 30 (16 to 483$)$ \\
\hline \multirow[t]{2}{*}{$\begin{array}{l}\text { Nonfatal } \\
\quad \text { reinfarction }\end{array}$} & Warfarin + Asp $v$ Asp & $6 \% \vee 10 \%$ & $41 \%(22$ to 56$)$ & 25 (16 to 53 ) \\
\hline & Warfarin $v$ Asp & $7 \% \vee 10 \%$ & $24 \%$ (1 to 41$)$ & 43 (22 to 1364$)$ \\
\hline $\begin{array}{l}\text { Thromboembolic } \\
\text { stroke }\end{array}$ & Warfarin + Asp v Asp & $1 \% \vee 3 \%$ & $47 \%(6$ to 70$)$ & 80 (41 to 797$)$ \\
\hline \multirow[t]{2}{*}{ Warfarin $v$ Asp } & Warfarin $v$ Asp & $1 \% \vee 3 \%$ & $47 \%(6$ to 70$)$ & 80 (41 to 721$)$ \\
\hline & & & RRI (Cl) & NNH (Cl) \\
\hline \multirow[t]{2}{*}{$\begin{array}{l}\text { Nonfatal major } \\
\text { bleeding }\end{array}$} & Warfarin + Asp v Asp & $2 \% \vee 0.7 \%$ & $249 \%$ (63 to 650$)$ & 60 (37 to 137$)$ \\
\hline & Warfarin $v$ Asp & $3 \% \vee 0.7 \%$ & $309 \%$ (93 to 767$)$ & 49 (31 to 93 ) \\
\hline
\end{tabular}

†Abbreviations defined in glossary; RRR, RRI, NNT, NNH, and $\mathrm{Cl}$ calculated from data in article.

$\S$ Composite outcome = death, nonfatal reinfarction, or thromboembolic stroke, whichever occurred first.

aspirin alone group (table); the 2 warfarin groups did not differ for these outcomes. The 3 groups did not differ for overall mortality. Both warfarin groups had higher rates for nonfatal major bleeding episodes than the aspirin alone group (table); the 2 warfarin groups did not differ for this outcome.

\section{Conclusion}

In patients who had an acute myocardial infarction, long term treatment with warfarin in combination with aspirin or warfarin alone led to a lower risk of the composite outcome of death, nonfatal reinfarction, or thromboembolic stroke than aspirin alone, but increased the risk of nonfatal major bleeding.

*See glossary.

$\dagger$ Information provided by author.

\section{COMMENTARY}

The trial by Hurlen $e t$ al will have a limited effect on clinical practice because the liabilities of an aspirin and warfarin combination are well known. In this trial, the marked increase in bleeding counterbalances the benefit of efficacy in the composite endpoint. The problems about the need for INR surveillance and the open trial design are also notable. The most important contribution of the trial is to show that aspirin alone is not adequate, and future trials of more attractive combinations, such as aspirin plus clopidogrel, or aspirin and an oral direct thrombin inhibitor, are in progress. Ultimately, improved efficacy without significant incremental bleeding is the goal for a patient friendly, post MI thromboprophylaxis strategy. Accordingly, although the current trial was well done, its main contribution is a proof of concept that aspirin monotherapy is insufficient. In select patients with left ventricular dysfunction or atrial fibrillation after MI, the aspirin and warfarin combination may be useful, but it is hoped that better strategies will be validated in the future.

Eric J Topol, MD Cleveland Clinic Foundation

Cleveland Ohio, USA

\section{Author's response}

The incidence of major nonfatal bleeding associated with warfarin did not counterbalance the benefit in terms of the composite endpoint (neither by number nor severity of disease). We believe that analysis by the intention to treat principle compensated for the open trial design. This trial stresses the importance of anticoagulation in addition to platelet inhibition.

M Hurlen, MD

$\mathrm{H}$ Arnesen, MD, PhD 